\title{
Correlation Analysis of Yield and Yield Components of Seven Soybean Cultivars on Weed Competition
}

\author{
Doni Hariandi ${ }^{1}$, Didik Indradewa ${ }^{2}$, Prapto Yudono ${ }^{2}$ \\ ${ }^{1}$ Graduate Student, Department of Agronomy, Faculty of Agriculture, Gadjah Mada University, Indonesia \\ ${ }^{2}$ Department of Agronomy, Faculty of Agriculture, Gadjah Mada University, Indonesia
}

\begin{abstract}
The research aims to determine the variable yield components that correlate to the yield of soybean cultivars and to obtain soybean cultivars that are able to maintain yield despite competition with weeds. This field research is arranged using split plot with three blocks as the repetition where the main plot is the weed treatments and those are weed-free, weeding in a critical period, and weedy. Sub-plot is the soybean cultivars which are Anjarmoro, Argomulyo, Burangrang, Gema, Gepak kuning, Kaba, and Wilis. The research's result shows the variable yield component effects to seed yield is the number of pod per plant, number of seed per pod and seed weight per plant. Cultivars which can survive from three kinds of the conditions (weed-free, weeded in a critical period, and weedy) are Anjasmoro cultivar and Kaba cultivar.
\end{abstract}

Keywords: Soybean, cultivar, weed, endurance, yield

\section{Introduction}

Soybean is one of the food commodities of Indonesia and also as a staple food other than rice. Soybean is a source of vegetable protein and widely consumed in Indonesia. Soybean demand in Indonesia is increasing from year to year but the production of itself is still sufficient according to Agricultural Ministry year 2015. Indonesian government still imports the soybean commodity from other country.

The decreasing of the soybean production is caused by many factors as location, low price, bad seed, also less technology (Adisarwanto dan Wudianto, 1998 cit. Hendrawan, 2000), another factor is also the weed competition.

Weed can decrease the quality production of the plant. Weed also could increase the quantity of the production of the plant. The weed also impacts on the plant's growth. The decrease of the plant production of soybean plant is caused by weed reach at the lever 18-76\% (Manurung and Syam'un 2003).

This research aims to determine the variable yield components which has correlation at the production of the of soybean cultivars and to achieve soybean cultivar that can produce better production.

\section{Materials and Methods}

The research was held at Education and Research Garden and Development (KP4) Gadjah Mada University which located at Kalitirto, Berbah, Sleman, Yogyakarta, Indonesia. This research started on November 2015 till March 2016.

Materials used are seven soybean seeds with different cultivars, fertilizer (Urea, SP-36 and $\mathrm{KC} 1$ ), and pesticide. The tools utilized for this research are farming tools, ruler, camera, rope, scissor, stationery, knife, cutter, plastic bag, paper bag, pail, scale, oven, and moisture tester.

This field research is arranged using split plot with three blocks as the repetition where the main plot is the weed treatments and those are weedy, weeding in a critical period, and weed-free. Sub-plot is the soybean cultivars which are Anjarmoro, Argomulyo, Burangrang, Gema, Gepak kuning, Kaba, and Wilis. Soybean cultivars are given by Balai Penelitian Tanaman Kacang-kacangan dan Umbi-umbian Malang, Indonesia.

The data result of observation uses ANOVA analysis and Duncan's New Multiple Range Test (DMRT) at 5\% level. The analysis uses correlation analysis to determine between variable yield components and the data result would also be analyzed using regression analysis. However, to evaluate cultivars that can survive on three kinds of conditions including weed-free, weeding in a critical period, and weedy would use statistic method with Genotype and Genotype by Environment Interaction Biplot (GGE Biplot).

\section{Results}

\subsection{Number of pod per plant}

The analysis result in Table 1 shows that the interaction between the weeds and cultivars toward the number of pod per plant. The weed-free treatment shows that Gepak kuning cultivar have highest number of pods per plant compared to the other cultivars. Kaba cultivar shows that the highest number of pods per plant in the weeding treatment, but it is not different with Gepak kuning kultivar, while on weedy treatment Gepak kuning cultivar shows the highest number of pods per plant, but not significantly different with Kaba cultivar. 


\section{International Journal of Science and Research (IJSR) \\ ISSN (Online): 2319-7064}

Index Copernicus Value (2013): 6.14 | Impact Factor (2015): 6.391

Table 1: The Number of pod per plant

\begin{tabular}{|c|c|c|c|c|}
\hline \multirow{2}{*}{$\begin{array}{c}\text { Cultivar } \\
\text { treatment }\end{array}$} & \multicolumn{3}{|c|}{ Weed treatments } & \multirow{2}{*}{ Average } \\
\cline { 2 - 4 } & Weed-free & $\begin{array}{c}\text { Critical } \\
\text { period }\end{array}$ & Weedy & \\
\hline Argomulyo & 26,72 ghij & 25,06 ghij & $18,72 \mathrm{ij}$ & 23,50 \\
\hline Gema & $42,31 \mathrm{cdef}$ & $42,09 \mathrm{cdef}$ & $16,95 \mathrm{j}$ & 33,78 \\
\hline Burangrang & $39,03 \mathrm{def}$ & $33,78 \mathrm{efg}$ & $22,83 \mathrm{hij}$ & 31,88 \\
\hline Anjasmoro & $40,16 \mathrm{def}$ & $41,17 \mathrm{def}$ & $28,19 \mathrm{ghi}$ & 36,51 \\
\hline Wilis & $52,03 \mathrm{bc}$ & $43,75 \mathrm{cde}$ & $32,53 \mathrm{fgh}$ & 42,77 \\
\hline Kaba & $55,72 \mathrm{~b}$ & $60,25 \mathrm{~b}$ & $35,50 \mathrm{defg}$ & 50,49 \\
\hline Gepak kuning & $79,17 \mathrm{a}$ & $55,61 \mathrm{~b}$ & $45,36 \mathrm{~cd}$ & 60,05 \\
\hline Average & 47,88 & 43,10 & 28,58 & $(+)$ \\
\hline CV \% & \multicolumn{4}{|c}{4,23} \\
\hline
\end{tabular}

Description: The number followed by the same letter in the column and row are different according to DMRT $\alpha 0.05$, $(+)$ showing interaction between treatments.

\subsection{Seed weight per plant}

The seed weight per plant of seven soybean cultivars was tested on their interaction effect (Table 2). The treatment of weed-free shows that all cultivars have the same seed weight per plant except for Argomulyo. This weeding in a critical period treatment shows that Anjasmoro cultivar has highest seed weight per plant compared to the other cultivars as Gepak kuning, Kaba, Wilis, and Anjasmoro kultivars.

Table 2: Seed weight per plant (g)

\begin{tabular}{|c|c|c|c|c|}
\hline \multirow[b]{2}{*}{$\begin{array}{l}\text { Cultivar } \\
\text { treatment }\end{array}$} & \multicolumn{3}{|c|}{ Weed treatments } & \multirow[b]{2}{*}{ Average } \\
\hline & $\begin{array}{l}\text { Weed- } \\
\text { free }\end{array}$ & $\begin{array}{l}\text { Critical } \\
\text { period }\end{array}$ & Weedy & \\
\hline Argomulyo & 5,04 efg & $6,07 \mathrm{cdef}$ & $2,55 \mathrm{jk}$ & 4,55 \\
\hline Gema & $6,76 \mathrm{bcd}$ & 5,06 efg & $2,15 \mathrm{k}$ & 4,66 \\
\hline Burangrang & 6,35 cde & 5,12 efg & $2,92 \mathrm{ijk}$ & 4,80 \\
\hline Anjasmoro & $6,87 \mathrm{bc}$ & $9,07 \mathrm{a}$ & 5,42 defg & 7,12 \\
\hline Wilis & 6,39 cde & $3,52 \mathrm{hij}$ & 4,17 ghi & 4,69 \\
\hline Kaba & $6,98 \mathrm{bc}$ & $7,83 \mathrm{~b}$ & $4,56 \mathrm{gh}$ & 6,46 \\
\hline Gepak kuning & 6,42 cde & $5,18 \mathrm{efg}$ & $4,93 \mathrm{fg}$ & 5,51 \\
\hline Average & 6,40 & 5,98 & 3,81 & $(+)$ \\
\hline$C V \%$ & & & & \\
\hline
\end{tabular}

Description: The number followed by the same letter in the column and row are different according to DMRT $\alpha 0.05$, $(+)$ showing no interaction between treatments.

\subsection{Number of seed per pod, 100 -seed weight and seed yield}

Table 3 reveals that there is no interaction between weed and the cultivars toward the number of seed per pod, 100-seeds weight and seed yield. The different effects were demonstrated by the main factors. Wilis and Anjasmoro cultivars has highest number of seed per pod, but it is not different from Argomulyo, Kaba, Gema and Gepak kuning kultivars, whereas Burangrang cultivar has the least of pod. Weight of 100 seed show that Burangrang, Anjasmoro, and Argomulyo cultivars are heavier and also those cultivars like Gema, Wilis, Kaba, and Gepak kuning.
The cultivar treatments would effect to seed yield, where Kaba, Anjasmoro and Wilis cultivars have seed yield highest than Gepak kuning, Gema, Burangrang and Argomulyo cultivars. Weed treatment would affect no significant difference in the number of seed per pod. Weed-free and weeding in a critical periode treatments would affect differently with weedy treatment of 100 -seeds weight and seed yield.

Table 3: The number of seed per pod (Seed), 100-seed weight $(\mathrm{g})$, seed yield (Ton $\left.\mathrm{Ha}^{-1}\right)$

\begin{tabular}{|c|c|c|c|}
\hline Treatments & $\begin{array}{c}\text { Number of } \\
\text { seed per pod }\end{array}$ & $\begin{array}{c}\text { 100-seed } \\
\text { weight }\end{array}$ & $\begin{array}{l}\text { Seed } \\
\text { yield }\end{array}$ \\
\hline \multicolumn{4}{|l|}{ Cultivars } \\
\hline Argomulyo & $1,85 \mathrm{ab}$ & $16,38 \mathrm{a}$ & $1,14 \mathrm{c}$ \\
\hline Gema & $1,78 \mathrm{ab}$ & $13,21 \mathrm{~b}$ & $1,32 \mathrm{c}$ \\
\hline Burangrang & $1,72 \mathrm{~b}$ & $16,76 \mathrm{a}$ & $1,29 \mathrm{c}$ \\
\hline Anjasmoro & $1,89 \mathrm{a}$ & $16,46 \mathrm{a}$ & $1,85 \mathrm{a}$ \\
\hline Wilis & $1,91 \mathrm{a}$ & $11,81 \mathrm{c}$ & $1,72 \mathrm{ab}$ \\
\hline Kaba & $1,82 \mathrm{ab}$ & $11,77 \mathrm{c}$ & $1,87 \mathrm{a}$ \\
\hline Gepak kuning & $1,75 \mathrm{ab}$ & $8,56 \mathrm{~d}$ & $1,47 \mathrm{bc}$ \\
\hline \multicolumn{4}{|l|}{ Weed treatments } \\
\hline Weed-free & $1,86 \mathrm{p}$ & $13,73 p$ & $1,68 \mathrm{p}$ \\
\hline Critical period & $1,77 \mathrm{p}$ & $13,77 p$ & $1,69 \mathrm{p}$ \\
\hline Weedy & $1,82 \mathrm{p}$ & $13,20 \mathrm{q}$ & $1,21 \mathrm{q}$ \\
\hline Interaction & $(-)$ & $(-)$ & $(-)$ \\
\hline$C V \%$ & 8,69 & 6,19 & 24,27 \\
\hline
\end{tabular}

Description: The number followed by the same letter in the column and row are different according to DMRT $\alpha 0.05$, (-) showing no interaction between treatments.

\subsection{Correlation and regretion}

The variable of the number of the pod per plant results significant and positive correlation with seed weight per plant with seed yield. The number of seed per pod positively correlates with seed yield, while seed weight per plant positively correlates with seed yield. This shows that number of pod per plant affects to seed weight per plant and seed yield. The increasing number of pod per plant would increase seed weight per plant and seed yield also the number of seed per pod and seed weight per plant. The increasing number of seed per pod and seed weight per plant would increase seed yield (Table 4 and Figure1).

Table 4: Correlation value between variable yield components and seed yield of soybean plant

\begin{tabular}{|c|c|c|c|c|c|}
\hline Variable & $N P P$ & $N S P$ & $S W P$ & $100-S$ & $S Y$ \\
\hline$N P P$ & 1 & & & & \\
\hline$N S P$ & $-0,014^{\mathrm{ns}}$ & 1 & & & \\
\hline$S W P$ & $0,547^{* *}$ & $0,187^{\mathrm{ns}}$ & 1 & & \\
\hline $100-S$ & $-0,583^{* *}$ & $0,026^{\mathrm{ns}}$ & $0,092^{\mathrm{ns}}$ & 1 & \\
\hline$S Y$ & $0,581^{* *}$ & $0,328^{*}$ & $0,697^{* *}$ & $-0,097^{\mathrm{ns}}$ & 1 \\
\hline
\end{tabular}

Description : NPP $=$ Number of pod per plant; NSP $=$ Number of seed per pod; SWP $=$ Seed weight per plant; 100$\mathrm{S}=100$-seeds weight; $\mathrm{SY}=$ Seed yield; $*=$ Significantly different at level $95 \%(\alpha=0,05)$. 


\section{International Journal of Science and Research (IJSR) \\ ISSN (Online): 2319-7064}

Index Copernicus Value (2013): 6.14 | Impact Factor (2015): 6.391

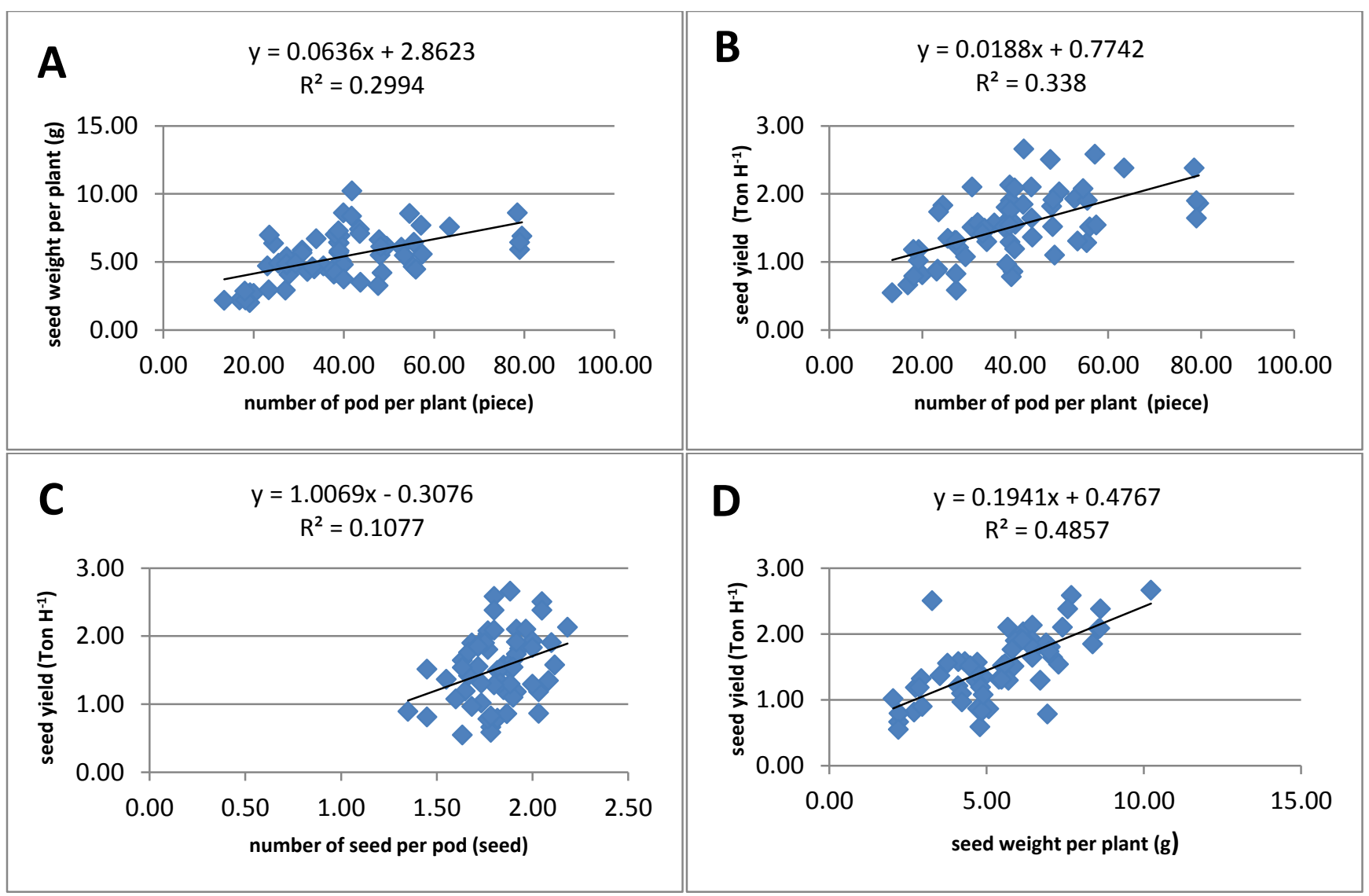

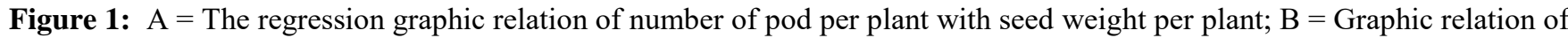
number of pod per plant with seed yield; $C=$ Graphic relation of number of seed per pod with seed yield, and $D=G r a p h i c$ relation of seed weight per plant with seed yield of soybean cultivars

\subsection{Genotype and Genotype by Environment Interaction Biplot (GGE Biplot)}

The indicators of the soybean cultivar endurance character toward the weed competition should be the main purpose of the research. The observation of the research of the soybean cultivar determines seed weight, and it becomes the indicator of soybean's endurance from weed.

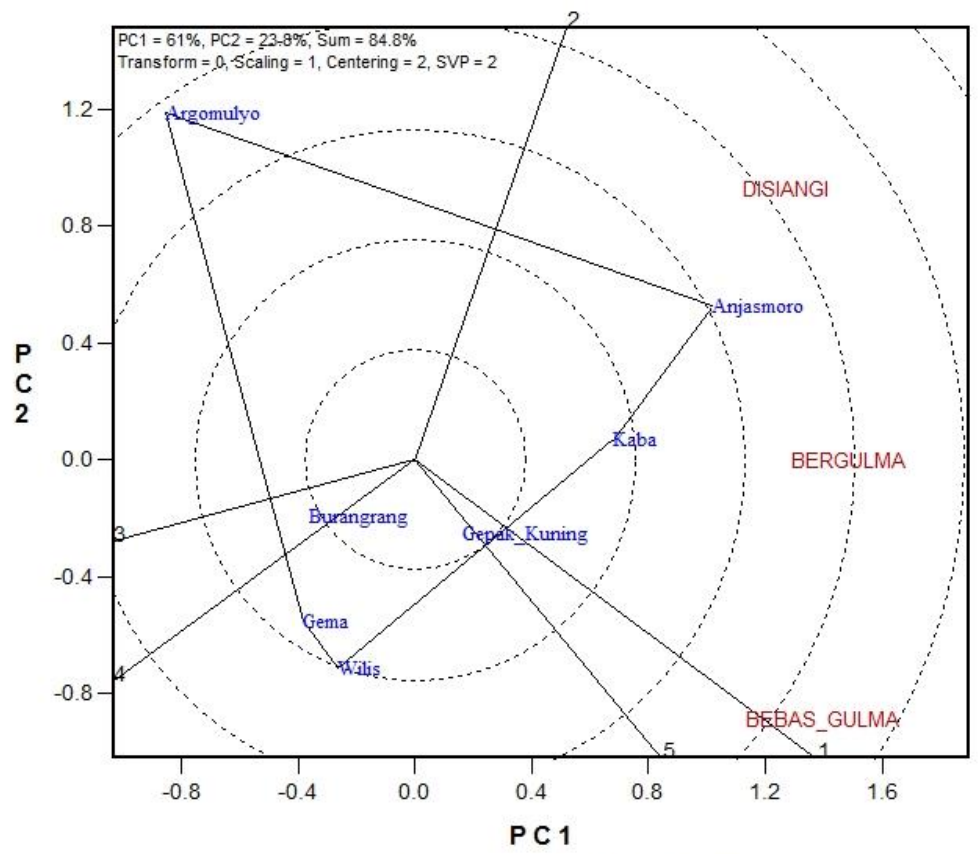

Which wins where or which is best for what

Figure 2: Poligon GGE-Biplot and the formats of which-wons-where on cultivar and environment (free weed, critical period, and weeding). $($ Description $:$ Bebas gulma $=$ Weed-free; Disiangi $=$ weeded in critical period; Bergulma $=$ weedy $)$

Volume 5 Issue 7, July 2016 www.ijsr.net 


\section{International Journal of Science and Research (IJSR)

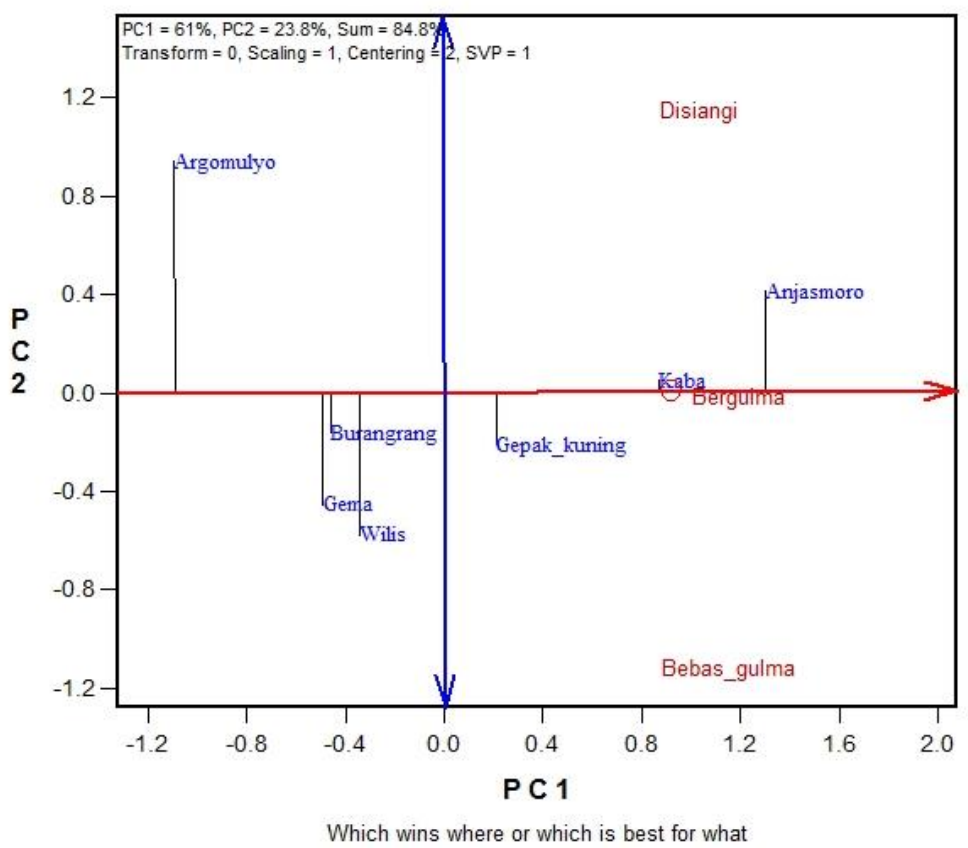

Figure 3: Average environment coordination (AEC) shows GGE-biplot based on environment focused scaling average result and plant stability. (Description : Bebas gulma $=$ Weed-free; Disiangi $=$ weeded in critical period; Bergulma $=$ weedy)

\section{Discussion}

The production of the crops is determined by the component treatment. The component treatments are genetic factor, environment, and nutrition (Ismunadji and Roechan, 1988; Yoshida 1981). Balbinot dan Fleck (2005) cit. Dias et al. (2011) states that the chosen cultivars have morphological characteristics and physiological to survive from the weed.

According to Dugje et al. (2009) weeding could inhibit the growth of the weed and it enhances the pod better. Nangju (1980) reports that soybean weeding could keep the nutrition intake including phosphor, kalium, nitrogen, and other micro nutrient also can enhance the number of pods. Soybean plant which is not weeded would produce less number of pod since the essential nutrition absorbed by the weed (humidity, sunlight, growing space, and other factors).

Van Acker et al. (1992) reports that the number of pod per plant is determined by the weed competition in the environment. Shading and increased dry matter of weed would decrease the number of pod per plant. Hume et al. (1985) states that the yield component like the number of pod relates to each other to the treatment.

Silva et al. (2008) cit. Hosseni (2015) states that there will be a significant decrease in the seed weight of soybean in weed competition on the plant. Meanwhile, Mohammadi and Amiri (2011) reports that the soybean seed weight decreases for $25,9 \%$ because of the competition between weed and the plant.

The plant capacity of producing the seed depends on the photosynthesis system, efficiency of the time and translocation of dry matter to economic yield. The seed yield is the cumulative function of yield components. The one factor of the increasing seed production is when the plant is weeded at the critical period and at the beginning of the growth since the dry matter is also increasing with better photosynthesis. So, there will be a good translocation of the nutrients to plant and plant would produce better seed characters (Toppo et al. 2012).

This research result shows that the weedy treatment could decrease weight of 100 seeds compared to the weed-free and weeded in critical period. This research result is in accordance with the research done by Halford et al. (2001) which states that the weight of 100 seeds could decrease along the increasing of the weed.

The research result is in accordance with the research invention of Pandya et al. (2005) reports that the increasing of the seed yield is determined by the weed treatment. The significant decrease of the seed yield is also caused by the characteristics of the weed as its broad leaves which can inhibit the growth of the main plant and it causes the decreasing of the yield.

This research result is in accordance with the research held by Mimber (1991) which states that the yield component and the soybean yield are determined by the number of pod per plant, number of seed per pod and seed weight.

Based on the analysis using statistic method the Genotype and Genotype by environment Interaction Biplot (CGE Biplot) also using the data of seed weight per plant, the three weed treatments are at the same zone (Zona 1) and the cultivars which are fine for all environment conditions also have good crop productions like Anjasmoro and Kaba cultivars (figure 2 and 43 ). 


\section{International Journal of Science and Research (IJSR) \\ ISSN (Online): 2319-7064}

Index Copernicus Value (2013): 6.14 | Impact Factor (2015): 6.391

\section{Conclusion}

1) This analysis shows the variable yield components effects to seed yield is the number of pod per plant, number of seed per pod and seed weight per plant.

2) According to the CGE Biplot analysis that uses data of seed weight per plant shows that cultivars could survive in three kinds of environment conditions (free weed condition and cleaned when the plants are in critical period or weeded), especially for Anjasmoro and Kaba kultivars.

\section{Acknowledgement}

The authors would like to thank the Indonesia Endowment Fund for Education (LPDP) for the financial support for this research.

\section{References}

[1] Dias, M.A.N., Pinto, T.L.F., Mondo, V.H.V., Cicero, S.M., Pedrini, L.G. 2011. Direct Effects of Soybean Pod Vigor on Weed Competition. Revista Brasileira de Sementes. 33(2): $346-351$.

[2] Dugje, I.Y., Omoigui, L.O., Ekeleme, F., Bandyopadhyay, R., Kumar, P.L., Kamara, A.Y. 2009. Farmers Guide to Soybean Production in Northern Nigeria. International Institute of Tropical Agriculture, Ibadan, Nigeria. pp. 21.

[3] Halford, C., Hamill, A.S., Zhang, J., Doucet, C. 2001. Critical Period of Weed Control in No-till Soybean and Corn. Weed Technology 15:737-744.

[4] Hendrawan. 2000. Pengaruh Kelembaban Tanah Terhadap Perkembangan Organ Generatif Beberapa Genotipe Kedelai. Skripsi. Fakultas Pertanian Universitas Sumatera Utara. Medan.

[5] Hosseini, S.Z., Firouzi, S., Aminpanah, $\mathrm{H}$ and Sadeghnejhad, H.R. 2015. Effect of Tillage System on Yield and Weed Populations of Soybean (Glycin Max L.). Annals of the Brazilian Academy of Sciences. Online version ISSN 1678-2690.

[6] Hume, D. F., Shanmugasundaram, S., and Beversdorf, W. D. 1985. Soybean(Glycine $\max$ L.). In Grain Legume Crops. Eds. R J Summerfield and E H Roberts. Collins Professional and Technical Books, London.pp.391-432.

[7] Ismunadji, M and Roechan, S. 1988. Hara Mineral Tanaman Padi. Padi I. Balai Penelitian dan Pengembangan Tanaman Pangan. Bogor. p.231-269.

[8] Manurung, J.P. dan E. Syam'un. 2003. Hubungan Komponen Hasil dengan Hasil Kedelai (Glycine max (L.) Merr.) yang Ditanam pada Lahan Diolah Berbeda Sistem dan Berasosiasi dengan Gulma. J. Agrivigor3 (2):179-188.

[9] Mimber, S.M. 1991. Pengaruh Kerapatan Tanaman terhadap Organ-organ Produksi Retensi Polong dan Hasil Kedelai Wilis. Universitas Brawijaya. Malang. p.60.

[10] Mohammadi, G.R.and Amiri, F. 2011. Critical period of weed control in soybean (Glycine max) as influenced by starter fertilizer. Aust J Crop Sci 5: 1350-1355.
[11]Nangju, D. 1980. Effect of Plant Density, Spatial Arrangement and Plant Type on Weed Control in Cowpea and Soybean. Weed and Their Control in the Humid and Subhumid Tropics. Proceedings of a Conference at the International Institute of Tropical agriculture. 288-299.

[12] Pandya, N., Chouhan, G.S., Nepalia, V. 2005. Effect of Varieties, Crop Geometries and Weed Management on Nutrient Up take by Soybean (Glycine max) and Associated Weeds. Indian J. Agron. 50(3):218-220.

[13] Toppo, A.R., Dewangan, D.K. and Lakpale, R. 2012. Effect of Integrated Weed Management Practices on Growth and Productivity of soybean (Glycinemax (L.) Merrill). International Journal of Forestry and Crop Improvement. 3(2) : 127-133.

[14] Van Acker, R. C., Swanton, C. J., Weise, S. F. 1993. The critical period of weedcontrol in Soybean (Glycine $\max$ L.). Wed Sci 41: 194-200.

[15] Yoshida, S. 1981. Fundamentals of Rice Crop Science. IRRI, Los Banos, Philippines. p.1-110.

\section{Author Profile}

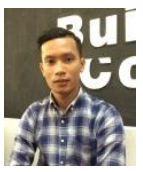

Doni Hariandi is a graduate student at Agriculture Faculty, Gadjah Mada University, Indonesia. He held BSc degree in Agroecotechnology from University of Andalas.

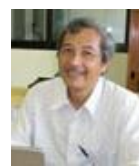

Prof. Dr. Ir. Didik Indradewa is senior lecture at Agriculture Faculty, University of Gadjah Mada, Indonesia. $\mathrm{He}$ held $\mathrm{BSc}$ degree and $\mathrm{PhD}$ from university of Gajah Mada.

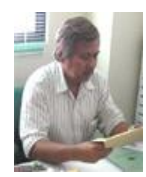

Prof. Dr. Ir. Prapto Yudono, M.Sc. is senior lecture at Agriculture Faculty, University of Gadjah Mada, Indonesia. He held BSc degree in plant breeding at University of Gadjah Mada, than MSc and PhD from University of the Phillippines. 